\title{
Factors essential for successful and sustainable e-learning
}

\author{
Ayanda Pamella Deliwe
}

Business Management Department, Nelson Mandela University, South Africa.

\begin{abstract}
E-learning has been viewed as a positive initiative in Higher Education Institutions (HEIs) as it is said to improve opportunities for critical thinking, develop better problem-solving abilities and assists in the improvement of productivity and efficiency of employees. For higher HEIs to benefit fully from the advantages of e-learning there needs to be continuous research done on how best can HEIs ensure that there is successful and sustainable e-learning. This paper focused on understanding what factors are needed for achieving successful and sustainable e-learning. Secondary data literature was reviewed and in collecting primary data six participants from one of the South African HEIs (UKZN) were interviewed. Information gathered through primary data collection was in line with the information obtained from the literature. The difference was when the primary data revealed additional factors which are essential for successful and sustainable e-learning. These include the importance of finances and regular discussions and engagements with champions/experts and researchers in the field of e-learning. Most of the literature highlights the importance of engagement with students, faculty and academic staff and not much emphasis is placed on engagements with all stakeholders. The paper concluded by providing recommendations that need to be considered by HEIs on how best they can achieve successful and sustainable e-learning.
\end{abstract}

Keywords: Effectiveness of e-learning; e-learning success; e-learning system readiness. 


\section{Introduction}

There is a need for new methods in the field of education, especially in the information society, which is Information Communication Technology (ICT) based (Kim, 2016). Humayun (2020) stated that the Covid-19 pandemic has resulted in a shift from the traditional modes of teaching to online learning. According to Blackburn (2016), e-learning improves opportunities for critical thinking, develops better problem-solving abilities and assists in improving employees' productivity and efficiency. He also stated that for Electronic Learning (e-learning) to be effective, investments must be made into teachers as facilitators rather than teachers as lecturers. E-Learning offers transformation and new opportunities for teaching and learning. It is essential to highlight that using technology does not fully promise or guarantee to make a difference in teaching and learning. What is important is how well technology is used in support of teaching and learning (Blackburn, 2016). This is true, as institutions can have all the improved technological systems but this does not guarantee the actual use of those systems, because stakeholders such as students and academic staff are those who must use the system. If they do not wish to use it, e-learning will not be a success. With e-learning, students have an opportunity to combine their learning experience with information technology advancement (Tarus et al., 2015). Promoting e-learning allows for developing countries to advance in the knowledge economy and it is viewed as the most costeffective way of facilitating the learning of large groups with the use of ICT (Tarus et al., 2015).

\section{Problem statement}

The South African higher education institutions (HEIs) are under immense pressure to increase the participation of a different group of students to produce the skills that are required in a rapidly changing labour market (Jaffer, Ng'ambi and Czerniewicz, 2007). There is a social demand for improved access to higher education and e-learning systems have become critical as competition in higher education institutions is increasing with most institutions needing to reduce costs while attracting more students (El-Masri and Tarhini, 2017). The introduction of e-learning brought numerous challenges for South African HEIs. Simelane (2011) added that these challenges are not only limited to South African HEIs but HEIs throughout the world. The challenges faced by South African HEIs include, but are not limited to, inadequate technical support and curriculum design, infrastructural constraints, limited resources, no institutional support, academic ability, low computer and internet access and a lack of ICT skills (Msomi, 2016). These challenges are no different from those found in other developing countries. Karunaratne, Peiris and Hansson (2018) confirmed that as much as ICT is used as a solution to enhance education, it has not always been successful because of many reasons including lack of funds, skills and motivation of stakeholders. The 
main aim of this study is to get a broader understanding of what are the factors which are essential in obtaining successful and sustainable e-learning.

\section{Literature Review}

The main purpose of the literature review is to provide a foundation of knowledge on the topic.

\subsection{Effectiveness of E-Learning}

It is important to provide suitable infrastructure and to overcome social and gender inequalities to ensure that e-learning becomes a success. These are all needed to enhance elearning so that the benefits of traditional face-to-face learning are not lost (Blackburn, 2016). Bari et al. (2018) added that the ICT skill of students can impact the effective use of different technological technologies. Therefore there is a need for relevant ICT skills which will contribute to ensuring that the learning process is effective, where students should be comfortable with using computers as this will minimise some barriers to social interactions. Blackburn (2016) recommended e-learning categories and their main influences and these are top-down and bottom-up approaches. The top-down category includes the improvement of directives of where we look at the legal environment, governance, strategy and finance and the bottom-up approach includes the improvement of suggestions through hands-on experience, observation, knowledge and research. Bezuidenhout (2018) argued that for elearning to be effective the impact and role of the distance educator (DE) need to be identified. The DE should be prepared to accept their appropriate roles in the ever-changing digital environment meaning that their competencies should be prepared. Furthermore, the DE needs to unlearn their old-fashioned/outdated habits and behaviours and learn new skills and behaviours which will help them in dealing with the digital era. Rothmann and Cooper (2015) agree that they have highlighted the vital need for training as a strategy that should be linked to the business needs, measurements of results and performance effectiveness of the HEIs.

\subsection{Factors Essential for E-Learning Success}

Karunaratne, Peiris and Hansson (2018) have identified several factors which are essential for successful and sustainable e-learning. These factors include focusing on the educator's perspective; commitment from all the stakeholders; having relevant resources, backup policies/strategies and guidelines, collaborating with both local and international ICT organisations and developing the educators professionally. Several other authors have written about the factors that are essential for successful and sustainable e-learning. These authors have different but similar views According to Vovides et, al (2014), Queiros and de Villiers (2016), Yew and Jambulingam (2015), and Bruhn-Suhr (2004) the factors essential for 
eLearning success includes, student engagements, Technical expertise, faculty engagement, infrastructure and support system, instructional support, students preparation, the competence of teachers, continuous evaluation and revision and the role of change agents.

\subsection{E-Learning Systems Readiness Assessment}

Several organisations have challenges in sustaining e-learning systems. One of the contributing factors is no proper assessment for organisational readiness for e-learning (Alshaher, 2013). To minimise the risk of failure, it is the responsibility of all organisations to assess their readiness for e-learning systems within their organisations. According to Odunaike et al. (2013), readiness can be defined as the presence of the factors that are needed for successful and sustainable e-learning. Alshaher (2013) proposed a model to be used when assessing e-learning systems' readiness. The author proposed the McKinsey 7S Model, which was developed by Tom Peters and Robert Waterman in the early 1980s when they worked at the McKinsey and Company consulting firm. The model comprises seven variables that all begin with the letter S, namely structure, strategy, systems, skills, style, staff and shared values/super-ordinate goals. In as much as the Covid-19 pandemic has forced universities to conduct their teaching and learning online, universities need to take a step back and assess their $7 \mathrm{~s}$ if they want their eLearning initiatives to be sustainable.

\section{Methodology}

The case study is the method that was adopted in the study. A qualitative study was chosen because the researcher wanted to get an in-depth understanding. UKZN was used as a case study. The researcher conducted one-on-one interviews with 6 participants made up of two support staff members, two management and two members who belong to the accreditation bodies at UKZN. The criteria that the researcher used for selecting the participants were stakeholders who use MOODLE regularly and who have been using MOODLE for at least 2 years. The information gathered from participants was recorded and the recordings were transcribed. Data analysis was done using the coding method where responses were coded into themes and patterns.

\section{Findings/Discussion}

Participants agreed that a combination of factors is required for e-learning systems to be a success. Well-trained staff and staff members who are willing to be trained. Nguyen, Newby and Macaulay (2015) indicated that there are several benefits that information technology provides for organisations and one of these benefits is a sustainable competitive advantage. This is the reason that staff members should be trained on how to use information technology so that the organisations can benefit from these IT benefits. It is important for ICS staff to be 
competent and to understand teaching pedagogies, as well as the software, so they can offer support to users. Proper IT infrastructure, where the server can handle anything that is put on it, networking, Wi-Fi, hardware and backups, maintenance of the MOODLE system and computer training for students who do not have the computer skills are all needed.

In dealing with engagement with staff and all stakeholders to minimise resistance: The most important role players in all organizations' activities are the stakeholders (Al-Sabawy, 2013). According to Maric (2013), educational institutions can have the best systems in the world but what is most important is the actual use of these systems by the stakeholders, as e-learning systems are no good unless perceived as useful by the stakeholders. One of the participants highlighted the importance of regular discussions and engagements with champions/experts and researchers in the field of e-learning so that the institutions can gain a broader understanding of how MOODLE works and how they can make it more effective.

Financially, money is needed to upgrade the system and to successfully implement elearning. According to Nguyen et al. (2015), information technology has encountered several challenges about implementation. Lack of resources, more specifically capital resources, has limited information technology skills. Baker (2016) highlighted the importance of money and that investing in students could have a positive effect on higher education students' outcomes. Policy-makers must be advised on the critical choices that they make regarding institutions' finances. Management has an important role in finances, as they allocate budgets. If management does not agree with the importance of e-learning, they will not understand the budget that is needed to ensure that e-learning becomes a success. According to Nguyen (2015), the execution of projects often fails or suffers due to a lack of support from management.

Evaluation of e-learning systems, for the institutions to gain an understanding and feedback from the users about their opinions of the current MOODLE system's performance in their challenges, so that the MOODLE system can be upgraded to make it more user-friendly. Thuseethan, Achchuthan and Kuhanesan (2014) hold that selecting the appropriate technique for the evaluation of the Learner Management System (LMS) depends on the complexity and functionality of that system. The authors suggested two approaches to evaluating LMS, namely evaluating the usability of the LMS and testing the effectiveness of the LMS.

These factors are essential for successful and sustainable e-learning and are supported by current literature on the subject, with several authors highlighting the importance of student engagements, technical expertise, faculty engagement, faculty support of teaching and learning, infrastructure and support systems, e-learning environment and infrastructure, institutional support, didactical standards, e-learning competence of teachers, the attitude of educators, presentation and delivery of course content, course development, course structure, students' preparation, student support, continuous evaluation and revision, evaluation and 
assessment and role of change agents (Vovides et al., 2014; Queiros and de Villiers, 2016; Yew and Jambulingam, 2015; Bruhn-Suhr, 2004).

There is however new information that has emerged from participants on the factors that are essential for the success and sustainable e-learning and these are finances and regular discussions and engagements with champions/experts and researchers in the field of elearning so that the institutions gain a broader understanding of how MOODLE works and how they can make it more effective. Most of the literature highlights the importance of engagement with students, faculty and academic staff and not much emphasis is placed on engagements with all stakeholders. Several participants stressed the importance of including all stakeholders in engagements.

\section{Conclusion}

It is evident from the information gathered that many factors contribute to ensuring e-learning becomes a success. Participants have raised their views on what they view as important. One of the most common things identified in the study is the importance of engagements. These engagements are not only limited to engagements with stakeholders within the HEIs but also engaging experts who started early with the implementation of e-learning as several things could be learned from them. The findings have led to several recommendations.

\section{Recommendations}

After conducting the research the researcher came to some valuable recommendations which are: Engagements are very important because every stakeholder needs to understand what elearning is all about because if there is resistance from stakeholders the e-learning initiative is bound to fail. Furthermore, there are experts in the field who can be used as part of engagements to find out how they have dealt with the challenges that they have faced in implementing e-learning. These experts have proven to be very valuable especially during the time of the Covid-19 pandemic that led to most universities having to do away with traditional face-to-face teaching to online teaching. These experts will greatly assist in finding easier yet efficient ways to offer courses that were previously not offered online to be offered fully online.

To minimise the risk of failure, it is the responsibility of all organisations to assess their readiness for e-learning systems within their organisations. In assessing readiness for elearning it is recommended that the model comprises seven variables that all begin with the letter S, namely structure, strategy, systems, skills, style, staff and shared values/superordinate goals. The structure will indicate the different roles, responsibilities and accountabilities, and usually has many layers. The strategy will assist in the transformation 
of the organisation from the current position to a new position, the systems will support the strategy and structure through formal and informal procedures. Skills which need to be improved to be able to work on the e-learning systems, style and culture are crucial as it indicates leadership style and staff which need to be trained and empowered properly on utilisation of e-learning systems. The seven variables will be easier to assess currently as most universities are offering most of their courses online. It is therefore not just to assess readiness but to check on how best can universities improve the variables to ensure that their online offerings are indeed beneficial to the stakeholders.

It is recommended that the e-learning effectiveness assessment be conducted by institutions to check how effective e-learning in their institutions is. This could be done by using Kirkpatrick's model which consists of four levels. These levels include; reactions, learning, transfer and results.

\section{References}

Al-Sabawy, A.Y., Cater-Steel, A., Soar, J., (2013). Measuring e-learning systems success. Doctoral dissertation, University of Southern Queensland. doi: 10.4018/978-1-46660170-3.ch015

Alshaher, A.A.F., (2013). The McKinsey 7S model framework for e-learning system readiness assessment. International Journal of Advances in Engineering \& Technology, Vol 6, No. 5, pp. 1948-1966.

Baker, B.D., (2016). Does money matter in education?. (2nd edition). Albert Shanker Institute. https://eric.ed.gov/?id=ED563793

Bari, M., Djouab, R. and Hoa, C.P., 2018. Elearning Current Situation And Emerging Challenges. People, International Journal of Social Sciences, Vol 4, No. 2. pp. 157-268. Doi: 10.20319/pijss.2018.42.97109

Bezuidenhout, A., (2018). Analysing the Importance-Competence Gap of Distance Educators With the Increased Utilisation of Online Learning Strategies in a Developing World Context. International Review of Research in Open and Distributed Learning, Vol 19, No. 3. pp. 262-281. Doi: 10.19173/irrodl.v19i3.3585

Blackburn, G., (2016). In my end is my beginning: E-Learning at the crossroads. Tojet, The Thurkish Online Journal of Educational Technology, Vol 15, No. 3, pp.87-97. https://eric.ed.gov/?id=EJ1106410

Bruhn-Suhr, M., (2004). Success Factors for efficient e-learning Development and Implementation, Best practice example at Hamburg University OLIM-Management for Executives. Online]. Available: http://www.eucen.eu Accessed (3 April 2018).

El-Masri, M. and Tarhini, A., (2017). Factors affecting the adoption of e-learning systems in Qatar and USA: Extending the Unified Theory of Acceptance and Use of Technology 2 (UTAUT2). Educational Technology Research and Development, Vol 65, No. 3, pp. 743 763. 
Gajendran, N., 2020. Blockchain-Based secure framework for elearning during COVID-19. Indian journal of science and technology, 13(12), pp.1328-1341.

Jaffer, S., Ng'ambi, D. and Czerniewicz, L., (2007). The role of ICTs in higher education in South Africa: One strategy for addressing teaching and learning challenges. International journal of Education and Development using ICT, Vol 3, No. 4, pp. 131-142. https://www.learntechlib.org/p/42220/.

Karunaratne, T., Peiris, C. and Hansson, H., (2018). Implementing small scale ICT projects in developing countries-how challenging is it?. International Journal of Education and Development using ICT, Vol 14, No. 1, pp. 118-140. https://www.learntechlib.org/p/183556/.

Kim, Y., 2016. Development of e-Competency Framework for e-Learning Instructional Designer. Indian Journal of Science and Technology, Vol 9, No. 26, pp. 1-6

Maric, I., (2013). Stakeholder Analysis of Higher Education Institutions. Interdisciplinary Description of Complex Systems, Vol 11, No. 2, pp. 217-226. DOI: 10.7906/indecs.11.2.4

Msomi, A.P., (2016). The Impact of E-Learning on Higher Education Transformation in South Africa. Towards Excellence in Educational Practices, researchgate.net, pp.40-49.

Nguyen, T.H., Newby, M. and Macaulay, M.J., 2015. Information technology adoption in small business: Confirmation of a proposed framework. Journal of Small Business Management, Vol 53, No. 1, pp. 207-227. doi: 10.1111/jsbm.12058

Odunaike, S., Olugbara, O. and Ojo, S., (2013). E-learning implementation critical success factors. Proceedings of the International MultiConference of Engineers and Computer Scientists 2013 Hong Kong, Vol 3, No. 4.

Queiros, D.R. and de Villiers, M.R., (2016). Online learning in a South African higher education institution: Determining the right connections for the student. The International Review of Research in Open and Distributed Learning, Vol 17, No. 5, pp. 165-185.

Rothmann, I. and Cooper, C.L., (2015). Work and organizational psychology. Routledge.

Simelane, S., (2011). Stakeholder support during the implementation of web-based courses in higher education. Education in a technological world: communicating current and emerging research and technological efforts, pp.406-413.

Tarus, J.K., Gichoya, D. and Muumbo, A., (2015). Challenges of Implementing e-Learning in Kenya: A Case of Kenyan Public Universities. International Review of Research in Open and Distributed Learning, Vol 16, No. 1, pp. 120-141.

Thuseethan, S., Achchuthan, S. and Kuhanesan, S., (2014). Usability evaluation of learning management systems in Sri Lankan universities. arXiv preprint arXiv:1412.0197.

Vovides, Y. Chalem S.B. Gadhula, R. Kebaetse, M, B. Nigussie, N. A. Suleman, F. and Nkomazana, O., (2014). A systems approach to implementation of e-learning in medical education: five MEPI schools journeys. Academic Medicine, Vol 89, No. 8, pp. S102S106. doi: 10.1097/ACM.0000000000000347

Yew, O.F. and Jambulingam, M., (2015). Critical Success Factors of E-learning Implementation at Educational Institutions. Journal of Interdisciplinary Research in Education Vol 5, No. 1, pp. 17-24.Van Goch, M. (2018). Creativity in liberal education before and after study commencement. 4th International Conference on Higher Education Advances (HEAd'18), 1475-1483. doi: 10.4995/HEAd18.2018.8228. 